\title{
Selected Efforts/Research in the Area of Early Warning
}

\author{
Susanne Schmeidl
}

The entries listed below are based on a very broad definition of early warning. Anyone involved in research on conflict prediction, mediation, and/or resolution is included as I believe that early warning, in order to be successful, must take into consideration a wide range of factors. In addition, I wish to encourage interaction among different participants who share an interest in early warning.

The following descriptions of efforts/research in the area of early warning are based on submissions to the Centre for Refugee Studies after request for the creation of a directory on "Who is Who and does What in Early Warning" was posted on the Internet. Thus, this list is incomplete by definition, excluding those efforts that for some reason have not come to the attention of the Prevention/Early Warning Unit at the Centre for Refugee Studies. The search for submissions to the directory is ongoing. If you or your organization have been omitted, please contact us in order to be included in the final directory. The final version will be done in cooperation with Jeremy Bristol at International Alert, London.

There are five kinds of entries: efforts undertaken by NGOs; United Nations' efforts; Governments or Govern- ment Efforts; Research Centres at Universities; and Individual Researchers. The difference between the last two is that the former is an organized research effort with an established research project, while the latter refers to a research project that is undertaken by one or two researchers. Most of the listings here are self-entries. Only in a very few circumstances did I include a research effort without an initial submission (these efforts are marked with an asterik [*]). Individual researchers were only included if they answered our request for information and provided enough material to be discussed. This section, therefore, is the most incomplete. If you wish to learn more about certain efforts/research you can contact the people identified.

As the author of this compilation, I take complete responsibility for any errors or misrepresentation that may have occurred during the research process. Any corrections for the larger directory should be directed to Susanne Schmeidl at the Centre for Refugee Studies (schmeidl@yorku.ca; Tel.: 416-736-5883; Fax: 416-736-5837). If you know of any efforts/research not mentioned here which you think ought to be included into the directory, please let us know.

\section{Early Warning Efforts by Non-Governmental Organizations}

\section{ACCESS}

Mary Lord, Executive Director

1511 K Street, NW, Suite 643

Washington, D.C. 20005, USA

Tel.: (202) 783-6050, 1-800-888-6033, toll free

Fax: (202) 783-4767

E-mail: access@4acces.org

http://www.bso.com/ access/

homepage

ACCESS was founded in 1985 as a nonprofit, non-advocacy information service on international affairs issues. In an effort to keep the public informed of important international developments, ACCESS publishes timely, impartial summaries of current issues, as well as overviews of the diverse perspectives contributing to the foreign policy debate.

Please contact ACCESS or their webpage for their publications and guides such as The ACCESS Guide to Ethnic Conflicts in Europe and the Former Soviet Union.

\section{Agency for Cooperation and Research in Development-ACORD}

Mark Adams, Research and Programme Officer (Horn of Africa)

Agency for Cooperation and Research in Development (ACORD)

Francis House, Francis Street

London, SW1P 1DE, United Kingdom

Tel.: (+44 171) 828-7611/7612

Fax: $(+44171) 976-6113$

E-mail: acord@gn.apc.org

ACORD is an international consortium of NGOs that implements development, rehabilitation and emergency programmes in Africa. The Consortium is independent of political and religious affiliations.

ACORD has been interested in conflict issues for a number of years, stemming from the widespread proliferation of conflicts in Africa which have affected almost all the programmes we have in the continent. ACORD currently coordinates a network of NGOs, academics and other interested organisations and individuals in the issues of conflict, development and peace, called CODEP. ACORD is also part of a consortium carrying out a three-year
ODA-funded research programme into Complex Political Emergencies.

ACORD has a range of interests that fall under the heading 'conflict,' but our primary focus is on issues directly relevant to development and emergency programming in Africa. Early warning is ane of those interests.

\section{Carter Center-Conflict Resolution Program*}

Harry Barnes, Director

One Copehill

435 Freedom Parkway

Atlanta, Georgia 30307, USA

Fax: (404) 420-5196

http://www.emory.edu/carter_center

The Carter Center is a nonprofit, nongovernmental organization founded in 1982 by former U.S. President Jimmy Carter and Rosalynn Carter. The Center is dedicated to resolving conflicts and fighting disease, hunger, poverty, and oppression through collaborative projects in the areas of democratization and development, global health, and urban revitalization. 
1995: International Guide to NGO Activities in Conflict Prevention and Resolution.

State of World Conflict Report: A Publication of the International Negotiation Network

\section{Council on Foreign Relations; Center for Preventive Action}

Dr. Barnett R. Rubin, Director

Center for Preventive Action

Council on Foreign Relations

58 East 68 th Street

New York, NY 10021, USA

Tel.: (212) 734-0400

Fax: (212) 517-4967

E-mail: brubin@email.cfr.org

The Center for Preventive Action is an initiative of the Council on Foreign Relations to study and test conflict prevention-to learn whether and how preventive action can work by doing it. Many of today's most serious international problemsethnic conflicts, failing states, and humanitarian disasters-could, potentially, be averted or ameliorated with effective early attention. Yet few have attempted to put this idea into practice, and even fewer have evaluated such attempts. The CPA uses the unique resources of the membership of the Council on Foreign Relations to address this lack of action and understanding.

The primary function of the CPA is to learn about conflict prevention by engaging the members of the Council in such efforts. The CPA sends teams to pre-explosion crisis areas. These teams map out a strategy to settle or manage the conflicts and then advocate action by appropriate governments and organizations, national and international, private and public:

- An Advisory Group of Council members, including diverse and experienced practitioners and experts, works in consultation with the CPA's professional staff to choose such pre-explosion areas of conflict for CPA action. The Advisory Group also assists in assembling the teams.

- The teams visit the area for approximately two weeks. There, they talk not only to politicians, but to business leaders, religious leaders, journalists, nongovernmental organizations, and anyone else who can contribute to their understanding of the conflict. The group investigates both possible terms of a settlement and methods of bringing about a settlement by com- bining incentives, sanctions, and mediation.

- Upon its return, the team presents a report or map of how to resolve or manage the conflict for review by the Advisory Group. The map is prepared in terms accessible to a wide policy audience. The CPA then publishes a report, briefs political and other leaders, writes articles and opinion pieces, instigates Congressional hearings and other actions. The Center seeks to deploy all the means at the command of the Council on Foreign Relations to mobilize the American and international communities to organize action to prevent conflict from escalating, or better, to resolve it.

- A CPA working group visited the South Balkans in December 1995 to study potential conflicts in Macedonia and Kosovo. The Center is also forming a working group on Nigeria. The group will both study ways out of the current transition impasse and address the broader political and economic structural decay in Nigeria.

The Center also collaborates with other organizations engaged in preventive action. In cooperation with the African American Institute, Refugees International, and Search for Common Ground, the Center has helped to organize the Burundi Policy Forum since January 1995. This Forum coordinates conflict prevention activities in Burundi of North American-based organizations with the U.S. government, the United Nations, and a similar European Burundi forum coordinated by International Alert in London. The Forum has become the focal point for discussion of Burundi in the United States, advocating a number of comprehensive policies on the part of the U.S. and other governments and supporting the peace efforts of the UN Special Representative of the Secretary General in Burundi.

The Center is funded by the Carnegie Corporation of New York, the Twentieth Century Fund (for joint projects), and the United States Institute of Peace (Burundi Policy forum).

\section{Forced Migration Projects*}

Arthur C. Helton, Director

Forced Migration Projects

Open Society Institute, New York, USA

Tel.: (212) 887-0634

Fax: (212) 489-8455
E-mail: refugee@sorosny.org http://www.soros.org/migmon.html

The Open Society Institute Forced Migration Projects monitor circumstances in different regions of the world in order to provide the international community with early warning of forced movements of people, and to identify the social, economic, and political conditions which may cause such dislocations. The Projects encourage early and effective humanitarian responses to migration emergencies; advocate the humane treatment of those unable to return; urge permanent solutions for those displaced; and promote measures that avert individuals' need to flee.

\section{International Alert}

Kumar Rupesinghe, Secretary General Jeremy Bristol, Early Warning Officer International Alert

1 Glyn Street, London, SE11 5HT, United Kingdom

Tel.: (+44 171) 793-8383

Fax: (+44 171) 793-7975

E-mail: intlalert@gn.apc.org

Please see the article in this issue for further information. In addition to the efforts described therein, Jeremy Bristol, in collaboration with Susanne Schmeidl at the Centre for Refugee Studies, York University, is working on a directory of all current early warning mechanisms and databases.

\section{InterWorks}

Jim Good

InterWorks

116 North Few Street

Madison, WI 53703, USA

Tel.: (608) 251-9440

Fax: (608) 251-9150

E-mail: 73414.2565@compuserve.com

InterWorks has worked with UNHCR for the past ten years in training for emergency management of refugee influxes. These trainings have been offered about three times a year, around the globe for the last ten years.

We have written several training pieces for different $U N$ agencies and others on Early Warning, including updates on this or that "new initiative" and some of the computer-based networks being set up. 


\section{Minnesota Advocates for Humanitarian Rights Conflict Prevention Project (MAHR)}

Janelle M. Diller, Project Consultant 2306 Dexter Ave.

Silver Spring, Maryland 20902-5014, USA

Tel.: (301) 593-9698

Fax: (301) 681-6745

E-mail:

dillerj\%smtpgatenlaw.georgetown.edu

Barbara Frey, Executive Director

MAHR

400 Second Avenue South, Suite 1050

Minneapolis, Minnesota 55401-2408, USA

Tel.: (612) 341-3302

Fax: (612) 341-2971

E-mail: mnadvocates@igc.apc.org

MAHR is preparing an Early Warning Handbook in an effort to help integrate the work of human rights groups with the conflict prevention process. The Handbook will present a methodology that can be characterized as a three-step process: (1) gathering information accurately; (2) evaluating and reporting significant information effectively; and (3) advocating early warning responses with key conflict prevention actors in ways that enhance the incorporation of human rights values into the conflict prevention process. The Handbook is intended to serve, among other readers, nongovernmental organizations and civic groups in the areas of potential or escalating conflict.

The Handbook will focus primarily on promoting conflict prevention through the use of human rights monitoring, reporting, and advocacy in situations which have not yet escalated to armed conflict. The proposed methodology will be offered to help defuse conflict in situations of tensions and disturbances, and to help manage root causes of conflict in postwar phases of reconstruction or transition. The methodology will not directly apply in situations of interstate or internal armed conflict or genocide.

The fact-finding section in the handbook will focus on documenting patterns of violations of either individual or group rights, rather than isolated instances of violations. Thematic focuses will be selected with reference to root causes of conflict; those focuses will likely implicate civil, political, labour, social, economic and cultural rights.

The handbook will include a survey and directory of significant early warning and conflict prevention mechanisms that are operational in situations short of armed conflict. Those mechanisms will include structures and activities of the United Nations and regional intergovernmental organizations and key international and regional nongovernmental organizations. Brief references may be made to certain mechanisms triggered in situations of armed conflict (e.g., peace enforcement actions under chapter VII of the United Nations Charter). Mechanisms under development but not yet operational will be excluded except where deemed to be of sufficient potential to merit attention.

\section{Partnership to Enhance the Effectiveness of Conflict Management}

Gordon Thompson, Executive Director Institute for Resource and Security Studies

27 Ellsworth Avenue

Cambridge, Massachusetts 02139, USA

Tel.: (617) 491-5177

Fax: (617) 491-6904

E-mail: irss@igc.apc.org

International Task Force

Berghof Centre for Constructive Conflict Management (Berlin)

Centre for Applied Studies in Interna-

tional Negotiations (Geneva)

Centre for Strategic and International

Studies (Washington)

Conflict Management Group (Cam-

bridge, MA)

Institute for Resource and Security

Studies (Cambridge, MA)

International Alert (London)

Partners for Democratic Change (San

Francisco)

Search for Common Ground (Washington)

PEECM is a partnership of international and indigenous NGOs. The partnership was established to improve the effectiveness of conflict management, a field that encompasses efforts to obtain early warning of conflict and interventions that seek to prevent, mitigate, transform or resolve conflicts. Participating NGOs independently pursue their own conflict management programs, but will work together to exchange information and identify opportunities for collaborative action. While many PEECM activities will have a regional focus, the partnership seeks to promote effective conflict management worldwide. The partnership is currently coordinated by the Institute for Resource and Security Studies (IRSS).

PEECM proposed to undertake a three-year pilot project in Bosnia, Croatia Hungary, Serbia, Slovakia, and Slovenia to benefit those countries and create new practices for wider application. Within the six countries, the project will develop a system for information exchange, will establish consultative mechanisms to pursue coordination opportunities, and will link up indigenous NGOs with each other. The activities will yield the following benefits:

- accessible, timely information exchange;

- empowerment of indigenous conflict management practitioners;

- improved coordination of conflict management programs;

- improved matching of conflict management capabilities to needs;

- better integration of conflict management with other humanitarian and peace building function; and

- the creation of bridges between: users and provides of conflict management services; government and nongovernment actors; and indigenous and international practitioners.

Gutlove, P., and G. Thompson. 1995. "The Potential Cooperation by the OSCE and Non-Governmental Actors on Conflict Management." Helsinki Monitor: Quarterly on Security and Cooperation in Europe, $6(3): 52-65$.

\section{PIOOM (Interdisciplinary Research Program on Root Causes of Human Rights Violation)}

Alex P. Schmid, Research Director Berto Jongman, Research Fellow/Data Maniager PIOOM c/o LISWO, Leiden University Wassenaarseweg 52 2333 AK Leiden, The Netherlands

Tel.: (+31 71) 5273-861

Fax: (+31 71) 5273-788

E-mails:

schmid@rulfsw.fsw.leidenuniv.nl jongman@rulfsw.fsw.leidenuniv.nl

PIOOM is a scientific research program, the aim of which is the reduction of human rights violations throughout the world. PIOOM is a Netherlands-based, independent, nonpartisan, nonprofit organization, promoting and engaging in research. PIOOM's research supports the work of Amnesty International and other 
human rights organizations, as well as $\mathrm{UN}$-agencies. It strives to lay bare the ideological, economic, social, cultural, historical and political roots that lead to human rights violations. PIOOM also strives to identify factors that inhibit human rights violations.

The Center for the Study of Social Conflicts (COMT) of Leiden University is the headquarters for PIOOM's international network of PIOOM associates who can be found in nearly fifty countries around the world. The initiator of PIOOM is J. D. Backer, Rear Adm. Rtd., and former Chairman of the Dutch section of Amnesty International. The PIOOM Foundation was established on October 4, 1988.

PIOOM's basic research programme consists of seven projects. These have been outlined in:

Schmid, A. P. Research on Gross Human Rights Violations: A Programme, 2nd enlarged edition, with commentaries by $C$. Flinterman, K. J. Gantzel, T. R. Gurr, and M. McClintock. Preface by A. J. F. Köbben, Leiden, COMT, 1989 (1988). 245p.

Two questions are central to the work of PIOOM:

1) What are the causal factors behind gross human rights violations?

2) What are the optimal strategies to counter contemporary human rights violations and to prevent future violations?

Project Titles (please contact PIOOM for further information):

1) Toward a Global Map of Gross Human Rights Violations Conflicts in the 1980s and Beyond

2) Determinants of Gross Human Rights Violations by State and State-Sponsored Actors in Domestic Conflicts, 1960-1990

3)-6) These projects deal respectively with Policy and Prison Officers as Gross Human Rights (GHR) Violators; The Military as GHR Violator, and Vigilante Groups and Death Squads as GHR Violators.

7) Determinants of the Independence and Impartiality of the Judiciary

We are also working on a proposal on the Early Warning of Refugee Migration.

Schmid, A. P. 1996 (ed.). Whither Refugee? Human Rights Violations and Refugees: Causes and Consequences. Proceedings of PIOOM Symposium of June 17, 1994. Leiden, LISWO. (forthcoming).
Jongman, A. J. 1996 (forthcoming) (ed.). Contemporary Genocides. Causes, Cases, Consequences. Leiden, LISWO. (forthcoming).

Schmid, A. P., and A. J. Jongman (eds). 1995. Monitoring Human Rights Violations. Boulder, Colorado: Westview Press.

Jongman, A. J., and A. P. Schmid. 1994. Monitoring Human Rights. Manual for Assessing Country Performance. Leiden, LISWO.

Crelinsten, R. D., and A. P. Schmid. 1994. The Politics of Pain. Torturers and Their Masters. Boulder, Colorado: Westview Press.

\section{Prevention/Early Warning Unit, Centre for Refugee Studies}

Howard Adelman, Director

Susanne Schmeidl, Coordinator

Prevention/Early Warning Unit

Centre for Refugee Studies (CRS)

York University

York Lanes, 3rd Floor, 4700 Keele Street

North York, Ontario, M3J 1P3, Canada

Tel.: (416) 736-5883

Fax: (416) 736-5837

E-mails: hadelman@yorku.ca

schmeidl@yorku.ca

We are currently engaged in several ongoing projects with the aim of developing an early warning network. The main goal is to develop a comprehensive academicNGO-policy consortium to create a workable, effective, economic and cost-recoverable early warning system to deal with humanitarian emergencies, complex emergencies and conflict areas. (See article in this issue for more detail.)

Second, Dr. Susanne Schmeidl and Jeremy Bristol of International Alert, London, are compiling a directory on existing early warning efforts worldwide. Their work, as well as that of others, will appear in a special issue of Refuge: Canada's Periodical on Refugees entitled "The Early Warning of Humanitarian Disasters."

Third, the Prevention/Early Warning Unit is overseeing electronic discussion group on early warning issues (EWNETL). The purpose of the group is to provide a platform for researchers (academic and non-academic) and policy makers to discuss issues related to early warning. This includes the exchange of research, ideas, information etc. on early warning. (See advertisement in this issue on how to join.)

Fourth, there will be a workshop on "The Synergy of Early Warning Research" at CRS on March 15-17, 1997. This workshop will address the issues and problems of early warning analysis. Leading aca- demics involved in early warning research and policy makers from governments and prominent international organizations will be in attendance. The integration of policy responses within academic research will ensure that the resulting early warning analysis will be sensitive to the needs of policy makers.

\section{The Strategy Group}

Larry Seaquist, Chairman, CEO

The Strategy Group

1280 21st Street, NW, Suite 904

Washington, D.C. 20036, USA

Tel.: (202) 544-5829

Fax: (202) 544-5831

E-mail: strategy@interramp.com

The Strategy Group is a new international "do tank" based in Washington, D.C. but with an international cast of issues and associates. One of our key projects is the "Venice Process," a major project conducted in association with UNESCO aimed at (in our alternative phrase for 'early warning') "Early Strategic Engagement." This applied early warning effort seeks to foster both the development of a theoretical basis for preventative interventions and the development of an international framework of processes and professional "doing early warning."

\section{Early Warning within the United Nations System}

\section{Early Warning Activity at the United Nations High Commissioner for Refugees*}

Udo Janz, Chief

Information and Research Management Centre for Documentation and Research (CDR)

United Nations High Commissioner for Refugees (UNHCR)

Case Postale 2500

CH-1211 Geneva Dépôt 2, Switzerland

Tel.: (+41 22) 739-8555

Fax: (+41 22) 739-7367

E-mail: janz@unhcr.ch

http://www.unicc.org//unhcr//pub/ refworld/refworld.htm

Development of indicators for the early warning of population movements, refugees and displaced persons. A pilot study is in progress applying indicators to a half-dozen countries.

Structured assessments of country situations likely to generate refugee flows: 
evaluate issues, developments, groups in conflict and international responses. Participates in UN inter-agency meetings on early warning; situation summaries available on request. REFWORLD CD-ROM published biannually.

REFWORLD on CD-ROM is a collection of databases developed by the UNHCR Centre for Documentation and Research (CDR). REFWORLD contains authoritative information on refugees including current country reports, legal and policy-related documents and literature references.

CDR is an information, research and training centre for UNHCR. It is dedicated to providing reliable and current information and analysis on all aspects relating to refugees and displaced persons, including their countries of origin, legal instruments, human rights, minorities, situations of conflict, and conflict resolution.

If you would like to subscribe to this valuable research tool, please write to the CDR at the address above or through email cdr@unhcr.ch.

\section{HEWS-Humanitarian Early Warning System}

\author{
Elizabeth V. Kassinis \\ Adeel Ahmed \\ Policy and Analysis Division \\ Department of Humanitarian Affairs \\ United Nations \\ New York, NY 10017, USA \\ Tel.: (212) 963-1143 \\ Fax: (212) 963-3115 \\ E-mails: kassinis@un.org \\ ahmeda@un.org
}

Prevention is the most effective way of reducing the human suffering and material destruction that are the inevitable results of conflict. As a well-recognized tool to assist the international community in achieving the goal of prevention, early warning has received an increasing amount of attention in the last few years. Using as its focal point the collection, analysis, and dissemination of early warning information in the humanitarian field, the Department of Humanitarian Affairs (DHA) has established the $\mathrm{Hu}-$ manitarian Early Warning System (HEWS). Setting up such a system was not seen as an end unto itself. Instead it was conceived as a way to support decision making with a well organized informa- tion base that pulls from a wide-reaching network. This tool is meant to ensure that decision-makers are better informed and have the maximum amount of time, and consequently a larger set of options, needed to prevent crises from erupting. It is evident that the number of options available to the international community decreases as a situation deteriorates or descends into violence.

The purpose of the HEWS is to compile and analyse information from a number of sources in order to identify potential crises with humanitarian implications. Currently, the database contains information on over one hundred countries, with more intense analysis of particularly vulnerable areas. Information is of two types, quantitative and qualitative, and includes reporting from the various early warning systems that exist, for example, in the food and agriculture sector. UN information, from both the headquarters- and field-levels, is supplemented with that from outside sources. Recognizing that much critical information and many useful insights rest outside of the $\mathrm{UN}$, the challenge has been to harness this expertise as and when appropriate.

Early warning is necessary but not sufficient to prevent or even prepare for crises. Credible signals must translate into early and effective action. Thus, information on potential crisis situations, such as the reports HEWS generates, are fed into the consultation processes that determine what actions should be taken either towards preventing crises or preparing for their impact. DHA is thus able to focus attention on situations of concern in discussions with its humanitarian partners as well as with other departments within the UN Secretariat.

\section{ReliefWeb}

Sharon Rusu

Head of Information Services

Information Management and External

Relations Branch

United Nations, Department of Hu-

manitarian Affairs (UNDHA)

8-14 avenue de la Paix,

CH1211 Geneva 10, Switzerland

Tel.: (+41 22) 917-2661

Fax: (+41 22) 917-0023

E-mail: sharon.rusu@dha.unicc.org

http://www/reliefweb.int

For a description please see the article on ReliefWeb in this issue.

\section{Selected Efforts of Governments/Governmental Organisations}

\section{State Failure Task Force*}

Jack A. Goldstone

Department of Sociology

University of California, Davis

Davis, California 95616-8701, USA

Tel.: (916) 752-0784

Fax: (916) 752-0783

E-mail: jagoldstone@ucdavis.edu

Ted Robert Gurr

Center for International Development

and Conflict Management (CIDCM)

Suite 0145, Tydings Hall

University of Maryland

College Park, MD 20742-7231, USA

Tel.: (301) 314-7706

Fax: (301) 314-9256

E-mail: tgurr@bss1.umd.edu

Pamela T. Surko

Science Applications International

Corporation

P.O. Box 1303

McLean, VA 22102, USA

Daniel C. Esty

School of Forestry and Environmental

Studies

Yale University

370 Prospect Street

New Haven, CT 06511, USA

Tel.: (203) 432-1602

E-mail: daniel.esty@yale.edu

Barbara Harff

Department of Political Science

U.S. Naval Academy

Annapolis, MD 21402, USA

Phone/Fax: (410) 293-6863

E-mail: harff@nimitz.nadn.navy.mil

This study was prepared in response to a request from Vice-President Gore. In July 1994, he asked the Central Intelligence Agency to work with outside experts to design and carry out a study on the failure of states. He asked that the consultants develop a methodology that would identify key factors and critical thresholds signalling a high risk of crisis two years in advance. He suggested going back forty years to identify examples of serious domestic crisis. The State Failure Task Force was established to take on this work. Composed of distinguished experts from academic institutions, data collection and management specialists from the Consortium for International Earth Science Information Network (CIESIN), analytic 
methods professionals from Science Applications International Corporation (SAIC), and senior government officials, the group met frequently in plenary sessions and in smaller units to address various aspects of the study.

The study is the first comprehensive empirical effort to identify the correlates of state failure. It analyses inductively some 600 possible contributing factors, many of them suggested by prior academic research on cases and causes of regime crisis and breakdown. Several simple but powerful models are identified that may help guide U.S. foreign policy makers.

In predicting specific country failures, the work is less fully developed. Indeed, the study has four significant limitations:

1) Data gaps and irregularities reduced the extent to which the role of some variables could be analysed.

2) Although associations were discovered between a number of variables and state failure, these linkages cannot be said to demonstrate cause and effect.

3) Although the task force developed models that discriminate between historical failures cases and control cases with an accuracy rate of about seventy percent, this same level of accuracy cannot be guaranteed on a forward look basis.

4) Given the qualified success in distinguishing failures from non-failures, input from country experts must continue to guide any assessment of future risks of state failure.

\section{Selected Findings}

Of the thirty-one variables identified as significant discriminators between the problem countries and the controls, the best predictors of state failure from 1955 to 1994 were high infant mortality and low trade openness. The relative effect of these two variables varied with a country's level of democracy. Low trade openness was more strongly associated with the risk of state failure in less democratic countries, while high infant mortality was more strongly associated with the risk of state failure in more democratic countries. In particular, rates of trade openness and infant mortality relative to the world median levels proved useful indicators of risks of state failure.

Funding

Central Intelligence Agency to Science Applications International Corporations.

\section{Report}

The senior consultants are preparing summaries of the study's initial results and implications for publication in scholarly journals. A request to make the full report generally available through the U.S. Government's Technical Information Service is pending decision in the VicePresident's office (9/96). In the interim, address queries to Ms. Leslie Arron, Contracts Manager, Science Applications International Corporation, P.O. Box 1303, McLean, VA 22102.

\section{U.S. Agency for International Development}

Heather S. McHugh, Sr. Research Analyst USAID/Center for Development

Information and Evaluation

PPC/CDIE/DI/R\&RS SA-18, Room 203G

Washington, DC 20523-1820, USA

Tel.: (703) 875-4974

Fax: (703) 875-5269

E-mail: hmchugh@usaid.gov

USAID is engaged in a variety of initiatives that deal, at least peripherally, with early warning. The Policy Bureau has sponsored two recent workshops on early warning of state collapse, one in 1994 and one in 1995. These workshops brought together USAID, U.S. Dept. of State, other U.S. government agencies, academics, NGO leaders, other donors, to discuss these issues. Also, USAID is part of the inter-agency Greater Horn of Africa Initiative, which has a team focused on early warning and prevention. The GHAI RADARS Team has had a number of early warning experts brief the team on their systems (Doug Bond, Ted Gurr, Lincoln Bloomfield, etc.). Most recently, USAID's Center for Development Information and Evaluation has been asked to prepare information on early warning systems and preventive action. As the designated researcher, Heather McHugh has written a short paper on preventive diplomacy, and an annotated bibliography on early warning systems.

\section{Academic Departments and Early Warning Research}

\section{CASCON-Computer-Aided System for Analyzing Conflicts}

Lincoln P. Bloomfield, Professor Emeritus Political Science

Massachusetts Institute of Technology (MIT)
77 Massachusetts Avenue, E53-470 Cambridge, MA 02139-4307, USA

Tel.: (617) 253-5262

Fax: (617) 258-6164

E-mail: cascon@mit.edu

CASCON is a computer-aided system on the analysis of conflicts. This project is a spinoff of many years of research under the direction of Lincoln Bloomfield at MIT on the subject of local conflict and its prevention. The results of that research, including the model on which CASCON rests, are explained in Bloomfield and Leiss (1969).

The software remained under development as a sideline, and an experimental DOS version on floppies was completed in the late 1980s, including a manual. The software has been developed by Bloomfield's associate Allen Moulton. MIT has been making that version available at cost to users who request it. A forthcoming book by Bloomfield (1996) will contain a new version of CASCON for Windows. The previous database consisted of sixty-six cases, while the new version has eighty-five coded by three experts each for 571 factors.

Bloomfield, L., and A. Leiss. 1969. Controlling Small Wars. Knopf.

Bloomfield, L. 1996. Managing Conflict at the Turn of the Century. St. Martin's Press. (forthcoming).

Bloomfield, L. 1994. "The Premature Burial of Global Law and Order: Looking beyond the Three Cases from Hell." The Washington Quarterly, 17(3):145-61.

\section{Center for Security Studies and Conflict Research*}

Kurt R. Spillmann, Director Andreas Wenger, Research Associate Center for Security Studies and Conflict Research

Swiss Federal Institute of Technology

Zurich, ETH Zentrum SEU

CH-8092 Zurich, Switzerland

Tel.: (+41 1) 632-4025

Fax: (+41 1) 363-9196

E-mail: wenger@sipo.reko.ethz.ch http://www.fsk.ethz.ch/abo_fsk.htm

Main Research Areas, Organizational Structure

The Center for Security Studies and Conflict Research, founded in 1986 and based at the Swiss Federal Institute of Technology in Zürich, is an independent academic institution researching and teaching in the fields of security policy and conflict analy- 
sis. It relies on a holistic concept of security encompassing military, political, economic, social and ecological dimensions. The work of the Center is focused on three main research areas:

1. Swiss security policy;

2. international, primarily U.S. and European, security policy;

3. basic conflict and peace research.

Within these broad topics, certain current developments are of special interest to the Center. Regarding the consequences of the end of the Cold War, the political upheavals in Europe, the quest for a new European security architecture, and the economic and political consolidation of the Western European nations, attention is devoted to the changing Swiss role in a volatile international environment. The Center is also closely following, and contributing to, the domestic debate on the official Swiss security policy concept. Furthermore, the Center's research is concerned with methodological approaches to risk analysis. In the realm of international security policy, the focus is on historical aspects of U.S. foreign and security policy, on the origins and the future development of the North Atlantic Treaty Organization (NATO), and on models for a new European security structure. Attention in the field of peace and conflict research is devoted to comparing relevant theories of conflict and war. Anthropological, structural, and-most recently-ecological explanations are included. This theoretical approach is complemented by empirical analyses of local and regional conflicts. The conflict research group is presently engaged in the Environment and Conflicts Project (ENCOP), in conjunction with external institutions.

The Center maintains an extensive list of publications on general subjects in the field. Please consult the web-page for a listing.

\section{Conflict Early Warning Systems (CEWS) Research Programme of the International Social Sciences Council.}

Hayward Alker, Coordinator, CEWS

School of International Relations

University of Southern California

VonKleinSmid Center, Room 328

Los Angeles, CA 90089-0043, USA

Tel.: (213) 740-2152

Fax: (213) 742-0281

E-mail: alker@rcf.usc.edu
Kumar Rupesinghe, Secretary General International Alert

1 Glyn Street

London, SE11 5HT, United Kingdom

Tel.: (+44 171) 793-8383

Fax: (+44 171) 793-7975

E-mail: intlalert@gn.apc.org

The research programme was designed as a scholarly, international social science response to Boutros Ghali's agenda for peace. It is focused on providing interdisciplinary knowledge that can be of help to the governmental, intergovernmental and nongovernmental members of the UN system with special interests in conflict prevention. Our first major project will be a coordinated study of conflict prevention successes and failures, with cases taken from Latin American, Asian, African, European experience. This research is funded by the Carnegie Corporation of New York on a two year grant. Tentative book title: Alarms and Responses: A Comparative Study on Contemporary International Efforts to Anticipate and Prevent Violent Conflict.

Alker, H., T. R. Gurr, and K. Rupesinghe. 1995. "Conflict Early Warning Systems: An Initial Research Program." Paper Presented at the Annual Meeting of the International Studies Association, Chicago, February 21-24.

\section{Department of Peace and Conflict Research, Uppsala University}

Peter Wallensteen

Department of Peace and Conflict Research

Uppsala University

Gamala Torget 3; Box 514

S-751 20 Uppsala, Sweden

Tel.: (+46 18) 18-23-52

Fax: (+46 18) 69-51-02

Telex: 76982 UPACS S

E-mail: peter.wallensteen@pcr.uu.se

The research activities can be divided into two areas: 1) the origins and dynamics of conflict and 2) conflict resolution and international security issues. The analysis of peace research is going as well as the production of research-based education materials.

1. The Origins and Dynamics of Conflict.

The Department has carried out several studies on wars and confrontations in recent history, and on economic dependencies and their significance for the outbreak of war (Wallensteen 1973; 1981; 1984).
The relationship between economics and superpower involvement in armed conflict has concerned several researchers. A comprehensive analysis of the links between raw material needs and superpower military interventions in the Third World has been done (Hammarström 1986/1993). Conflicts concerning resources in particular regions, i.e. the South China Sea, are now being analysed. Another factor has been starvation and food prices in connection with internal and interstate conflicts in Africa and Asia (Wallensteen 1988a). Related to this field are studies on the linkages between environmental degradation and conflict (Swain 1993a; 1993b). An ongoing project on this theme is investigating environmentally induced population migration and its contribution to native-migrant conflicts in South Asia (Swain). Research attention has recently been given to global water issues (Wallensteen, Swain).

A major project deals with the diffuse effects of military conflicts across regions, between 1919 and 1992. Using a comparative perspective, this project attempts to analyse the interaction processes and regional contexts through which interstate conflict diffusion occurs (Hammarström 1993a; 1993b; 1994).

One study focuses on the links between domestic problems and interstate conflict (Heldt), and another deals with the escalation of ethnic conflict (Melander). The links between changes in military capabilities and the escalation of protracted conflicts are also studied (Holmberg).

Data on armed conflicts are continuously collected and statistics on major armed conflicts have been published in the SIPRI Yearbook since 1988. As of 1993 a list of all armed conflicts appears in Journal of Peace Research. This is a basic resource primarily for research. Regularly a report of all armed conflicts is published on a regular basis, entitled States in Armed Conflict (Wallensteen 1989, K. Lindgren 1991, Heldt 1992, Axell 1993, Nordlander 1994, Sollenberg 1995). The information has been used to study civilian casualties in 'wars (Ahlström \& Nordquist 1991).

2) Conflict Resolution and International Security Issues

An important concern is the issue of durable conflict resolution. This includes development of concepts and theory (Wallensteen, Nordquist, Heldt) and empirical studies of specific types of conflicts and areas (Nordquist 1983/1992). In par-

Refuge, Vol. 15, No. 4 (1996) 
ticular, the durable settlement of border conflicts has been studied (Nordquist 1992). In this context, studies on conflict resolution and peacekeeping in Southeast Asia and Asia Pacific have been completed (Amer 1989; 1993).

A comprehensive textbook on conflict resolution has recently been published, in Swedish (Wallensteen 1994b). An interest in mediation processes has also emerged (Wallensteen 1991, Nordquist). An ongoing project is studying the dynamics of integration as a parallel process, where integration may be a cause of conflict as well as a process towards enduring conflict resolution (Äsberg).

Several regional studies are also undertaken. Please consult to the WWWpage or write to the department for information. Also consult the web-page for an extensive list of publications.

Promoting Peace Research: The development of the field of peace and conflict research is analysed in Peace Research: Achievements and Challenges (Wallensteen 1988 b), with contributions from several noted researchers in the international peace research community. One particular effort was the development of the Uppsala ethical principles for researchers (Journal of Peace Research, 1984, Vol.21, No. 4).

The 1993 Executive Seminar on Conflict Prevention and Conflict Resolution. Executive Summary. Uppsala: Dept. of Peace and Conflict Research.

States in Armed Conflict (1988-1994) Dept. of Peace and Conflict Research. Several editors: Wallensteen, P. (1989); Heldt, B. (1992), Axell, K. (1993), Nordlander, Y. (1994), Sollenberg, M. (1995).

Wallensteen, P. 1973. Structure and War: On International Relations, 1920-1968. Stockholm: Rabn \& Sjögren.

Wallensteen, P. 1981. “Incompatibility, Confrontation and War: Four Models and Three Historical Systems, 1816-1976." Journal of Peace Research, Vol. 18, No, 1.

Wallensteen, P. 1988b. Peace Research: Achievements and Challenges. Boulder: Westview.

Wallensteen, P. 1991. “Is There a Role for Third Parties in the Prevention of Nuclear War?" In Behaviour, Society and Nuclear War, edited by P. E. Tetlock et al. New York: Oxford University Press.

\section{Early Warning of Genocides and Politicides}

Barbara Harff, Principal Investigator

Michael Dravis, Research Assistant (see

also Minorities at Risk)

Department of Political Science

U.S. Naval Academy

Annapolis, MD 21402, USA

Phone/Fax: (410) 293-6863

E-mail: harff@nimitz.nadn.navy.mil

The research focuses on testing sequential models of the causes of genocide and mass political murder (politicide). The model identifies background and intervening conditions plus types of "accelerators," defined as "events that rapidly increase the level or significance of the most volatile of the general conditions." Multiple categories of accelerators are specified and information on them was gathered systematically for 18-month periods prior to the onset of genocidal or near-genocidal violence in Rwanda, Burundi, Bosnia, and Abkhazia. Some kinds of accelerators were present in much greater numbers immediately prior to the onset of the two clear-cut cases of genocide (Rwanda, Bosnia) than in the other two cases. The results suggest that monitoring and analysing accelerators is a potentially nearreal-time method for systematic early warning of impending genocide.

\section{Sources of Funding}

\section{See Minorities at Risk}

\section{Future Research}

Additional comparative case studies are planned. One objective is to test the generalizability of the findings of the initial studies. The second is to identify points in the sequence at which different kinds of preventive diplomacy and other interventions have been attempted, and to assess their effectiveness or lack of effect in checking the onset and escalation of violence.

Harff, B. 1992. "Bosnia and Somalia: Strategic, Legal, and Moral Dimensions of Humanitarian Intervention," Report from the Institute for Philosophy and Public Policy (University of Maryland, College Park) 12(3/4):1-7.

Harff, B. 1994. "A Theoretical Model of Genocides and Politicides." Journal of EthnoDevelopment. 4(July):24-30.

Harff, B., and T.R. Gurr. 1995. "Victims of the State: Genocides, Politicides and Group Repression from 1945 to 1995." PIOOM Newsletter and Progress Report. (7 Winter):24-38.
Gurr, T. R., and B. Harff. 1996 (forthcoming). Early Warning of Communal Conflict and Genocide: Linking Empirical Research to International Responses. Tokyo: UN University Press.

\section{Early Warning in Russia}

Eugene Kritski, Director

North Caucasian Centre

Institute for Social and Political Re-

search

Russian Academy of Science

PO Box 63, 350048 Krasnodar, Russia

E-mail: kritski@eawarn.kuban.su

I have been am a member of the Network of Ethnological Monitoring on Early Warning of Ethnic Conflict sponsored by the Institute of Ethnology \& Anthropology (Russian Academy of Sciences) and Conflict Management Group (Harvard University) since 1993. I also collaborate with the Network of Ethnic Studies (Ulster University) and other organisations dealing with the problem of early warning. Members of our network are currently working on creating a model of early warning which will monitor interethnic tension. This work is in its initial stage.

The North-Caucasian branch of the Institute of Social and Political Research makes use of social studies including surveys, public opinion polls etc. My latest research, entitled Chechen Crisis in Mass Consciousness of the Population of North Caucasus (sample $=4000$ respondents), analysed the perception of the war in Chechnia by the inhabitants of contiguous regions, ethnic status, ethnic stereotypes, and used them as indicators of potential interethnic conflicts. This study was published in Moscow in 1995.

Currently, I am working on a project entitled "Mass consciousness in the zone of conflict and war," which will entail field research in Chechnia.

\section{ENCOP-Environment and Conflicts Project*}

Kurt R. Spillmann, Director

Center for Security Policy and Conflict

Research

ETH-Zentrum

8092 Zurich, Switzerland

Tel.: (+41 1) 632-4025/4020

Fax: +(41 1) 363-9196

E-mail: encop@sipo.reok.ethz.ch

http://www.fsk.ethz.ch/encop/ 
Guenther Baechler, Executive Director

Swiss Peace Foundation

Wasserwerkgasse 7, P.O. Box

3011 Bern, Switzerland

Tel.: (+41 31) 311-5582

Fax: (+41 31) 311-5583

E-mail: chfried@dial.eunet.ch

Environmental pollution and ecological degradation are becoming ever greater causes of conflict. There have always been wars over scarce non-renewable resources. But only in our time has the nonsustainable exploitation and misuse of vital renewable resources such as soil, vegetation, water, and air become a main topic in both domestic and international politics. The trans-border character of these ecological problems turns them into a source of conflicts between states. By jeopardizing the natural base for economic and social development and causing migration movements, environmental degradation can also lead to internal revolts and violent clashes between ethnic groups.

Environmental problems are seldom the only cause of conflicts. However, when interwoven with such elements as population growth, poverty and injustice they increasingly contribute to existing and future political tensions. The avoidance or peaceful settling of conflicts induced by environmental degradation will be one of the most pressing of mankind's problems in the near future. Research done at ENCOP includes:

1. The role of desertification and environmental refugees in the civil war in Sudan;

2. The impact of climate change, deforestation and water diversion on the intra/interstate relations in Bangladesh;

3. The influence of ecological degradation on ethnic relations in Nigeria;

4. The struggle over shared water resources in the Middle East;

5. Water scarcity and soil degradation as a source of conflicts in central Asia

6. Environmental stress, ethnic cleansing, and tribal conflict in Rwanda;

7. Large-scale mining and environmentally induced conflicts.

ENCOP publishes a series of Occasional Papers representing intermediate results of the project. Check the web-page for more information.

\section{GEDS (Global Event-Data System) - PROJECT-University of Maryland}

John L. Davies, Director, GEDS Project Center for International Development and Conflict Management

and Department of Government and Politics

Tydings Hall Rm. 0145

University of Maryland

College Park, MD 20742, USA

Tel.: (301) 314-7709

Fax: (301) 314-9256

E-mail: jdavies@bss1.umd.edu

The GEDS Project is an ongoing effort to develop a system for tracking international and domestic interactions worldwide, providing narrative and analytical descriptions of events from on-line news reports, including codings (inter alia) for conflict intensity, level of cooperation, parties directly and indirectly involved, issue type, casualties, etc. The GEDS data can begenerated near-real-time as needed for early warning purposes, and can be further coded for specific "accelerator" categories described in early warning models such as those developed by Ted Robert Gurr and Barbara Harff (see the Minorities at Risk and Genocide Project). Current research projects include evaluations of the models developed by Gurr and Harff; use of COPDAB (Conflict and Peace Data Bank)-scale time-series data on conflict intensity to predict outbreak of civil war; and development of a capacity for automated pre-coding of events to allow for broader coverage of near-real-time events than is possible with computer-assisted human coding. Dynamic GEDS data is also being interfaced with structural data profiling states and non-state communities (initially Gurr's Minorities at Risk and Polity data) and episodic data (initially Wilkenfeld and Brecker's International Crisis Behaviour data) to provide more comprehensive early warning materials.

Davies, John L., and Chad K. McDaniel (1994). "Event Data and Software for Early Warning." Journal of Ethno-Development, 4(1):72-76.

\section{Global Early Warning System for Displaced Persons (Forced Migration)-GEWS}

Akira Onishi, Director

Institute for Systems Science

Soka University,

1-236 Tangi-Cho, Hachioji-shi

Tokyo 192, Japan
Tel: $(81-426) 91-9420$

Fax: (81-426) 91-9431

homepage: http://

suissgate.t.soka.ac.jp/

E-mail: onishi@t.soka.ac.jp

Global Early Warning System for Displaced Persons (Forced Migration) was founded in 1984. The FUGI (Futures of Global Interdependence ) global model designed by Onishi can be used as a global early warning system for displaced persons (forced migration) because it classifies the world into 180 countries and regional groups where each country and/ or regional model has four major subsystems such as (1) the environment; (2) development; (3) peace and security; (4) human rights. GEWS predicts the possible occurrence of displaced persons (forced migration) using the following indicators: (1) the destruction of the environment; (2) failures in development; (3) a lack of peace and security; and (4) the violation of human rights in each country or region.

Onishi, A. 1986. "A New Generation FUGI Model-A Global Early Warning System for National and International Conflicts." In Contributions of Technology to International Conflict Resolution, edited by $\mathrm{H}$. Chestnut, 39-55. IFAC: Pergamon Press.

Onishi, A. 1987. "Global Early Warning System for Displaced Persons: Interlinkages of Environment, Development, Peace and Human Rights." Journal of Technological Forecasting and Social Change, Vol. 31(3).

Onishi, A. 1990. "Uses of Global Models: A New Generation FUGI Model for Projections and Policy Simulations of the World Economy." International Political Science Review, Vol. II (No.2):280-93.

Onishi, A. 1995. "FUGI Global Model as GEWS (Global Early Warning System Model)." In The Proceedings of the 1995 Summer Computer Simulation Conference, edited by T. I. Oren and L. G. Birta, 1070177. Ottawa, Canada: SCS

Global Modelling Research: Toward the Development of a Conflict Alert System

Peter Brecke

School of International Affairs

Georgia Institute of Technology

Atlanta, GA 30332-0610, USA

Tel.: (404) 894-6599

Fax: (404) 894-1900

E-mail: peter.brecke@inta.gatech.edu

Refuge, Vol. 15, No. 4 (1996) 
http://www.inta.gatech.edu/peter/ globmod.html

The overall project is to develop a Conflict Alert System, a computer-based system that generates alerts that a violent conflict is going to erupt in some country or region anywhere in the world in three to twelve months. There are several sub-projects associated with this main efforts.

\section{1) Identifying configurations of conflict early warning indicators}

This sub-project involves searching for combinations-in the form of particular configurations - of indicators that have consistently appeared before different kinds of violent conflicts in the past. Once found, probability statements can be attached to the configurations to the effect that "When we see this configuration, eighty-eight percent of the time a conflict of this type could erupt within twelve months." The idea then would be to monitor countries and alert policy makers when a certain configuration associated with conflict potential is observed. In order to find specific configurations several issues need to be addressed: a) methods need to be developed that can apply pattern recognition techniques to conflict early warning indicators; b) indicators, when in combination with each other create the harbinger configurations, need to be identified; $c$ ) data corresponding to the indicators needs to be collected; d) different types of violent conflicts need to be specified; and e) finally pattern recognition techniques need to be applied to the data collected. The first component of this sub-project is complete. I am working with students to complete the other pieces.

\section{2) Development of computer software for a conflict alert system}

For an analyst whose job is conflict early warning, the question to ask is, "how should the computer program look and operate so that the analyst can easily receive and interpret the information that caused the program to generate an alert?"

3) Development of a taxonomy of violent conflicts ranging from global or systemic wars to struggles for turf by warlords

I am convinced that we will not be able to develop a working conflict alert system until we carefully and precisely specify different kinds of conflicts. Going through the literature, I have come up with a list of over 100 different kinds or types of violent conflicts. To create a taxonomy, I am as- sembling a database containing a list of all violent conflicts from 1495 to the present. The list looks like it will be in excess of 3,000 cases. For each case I will identify the conflict according to its status with respect to different criteria that distinguish different conflicts. (Existing typologies are useful in providing some of the criteria.) After assembling the database, I will use the clustering techniques that numerical taxonomists use to generate a hierarchical taxonomy of violent conflicts.

Brecke, P. 1995. Response section of a Forum on "An Early Warning System for the United Nations: Internet or Not?" Mershon International Studies Review 39(2):315-26.

Brecke, P. 1995. “Using Neural Networks to Find Harbingers of Violent Conflicts in Descriptions of Country Situations." Paper 95-3 in the Working Papers Series of the Georgia Consortium on Negotiation and Conflict Resolution, Georgia Institute of Technology

Brecke, P. 1995. "Using Neural Networks to Find Harbingers of Violent Conflicts." Paper presented at the IFAX/SWIISConference, Vienna, Austria. (The paper will be published in the Proceedings of the conference by Pergamon Press in 1996.)

\section{Kansas Event Data System (KEDS)}

Philip Schrodt, Principal Investigator Deborah Gerner, Principal Investigator Phillip Huxtable

Department of Political Science

University of Kansas, Blake Hall

Lawrence, Kansas 66045, USA

Tel.: (913) 864-3523

Fax: (913) 864-5700

E-mails: p-schrodt@ukans.edu

d-gerner@ukans.edu

phuxtabl@falcon.cc.ukans.edu

The KEDS project has focused on the development of a Macintosh computer program that can be used to generate political event data directly from the machine readable newswire reports available on data sources such as Nexis. The computer program and its coding dictionaries are available without charge to interested researchers, and we also can provide event data sets that have been coded using KEDS. We have completed two data sets covering the principal actors in the Arab-Israeli conflict for 1979-1995; one set is coded with the WEIS event data system and the other with BCOW (Behavioural Correlates of War) codes. We continue to maintain these data sets and are working on new sets covering domestic and international conflicts in the Persian Gulf, West Africa, and the former Yugoslavia. To date, most of our efforts have focused on the development of the program and the coding dictionaries. We have only recently begun working on statistical techniques specifically directed at early warning using event data. We anticipate completing several substantive papers focusing on statistical early warning techniques in the next two years.

Gerner, Deborah J., Philip A.Schrodt, Ronald A. Francisco, and Judith L. Weddle. 1994. The Machine Coding of Events from Regional and International Sources. International Studies Quarterly, 38:91-119.

Schrodt, Philip A. 1994. "Event Data in Foreign Policy Analysis." In Laura Neack, Jeanne A.K. Hey, and Patrick J. Haney, Foreign Policy Analysis: Continuity and Change. New York: Prentice-Hall, pp. 145-66.

Schrodt, Philip A., and Deborah J. Gerner. 1994. "Validity assessment of a machine-coded event data set for the Middle East, 1982-1992." American Journal of Political Science, 38:825-54.

Schrodt, Philip A., Shannon G. Davis, and Judith L. Weddle. 1994. "Political Science: KEDSNA Program for the Machine Coding of Event Data." Social Science Computer Review 12(3):561-88.

\section{The Lester B. Pearson Canadian International Peacekeeping Training Centre*}

\author{
Alex Morrison, President \\ Cornwallis Park \\ P.O. Box 100 \\ Clementsport, Nova Scotia, B0S 1E0 \\ Canada
}

Tel.: (902) 638-8041

Fax: (902) 638-3344

E-mail:

president@ppc.cdnpeacekeeping.ns.ca

The Pearson Peacekeeping Centre (PPC), a division of the Canadian Institute of Strategic Studies, provides research, education and training in all aspects of peacekeeping, and serves as a single focal point for peacekeeping information and activities. It is named in honour of Lester B. Pearson, former Prime Minister of Canada. In 1956, at the time of the Suez Crises, he invented peacekeeping for which he was awarded the 1957 Nobel Peace Prize. 
To guide its activities, the PPC has developed the concept of the "New Peacekeeping Partnership." The term is applied to those organizations and individuals which work together to improve the effectiveness of modern peacekeeping operations. It includes the military; civil police; governments; nongovernmental agencies dealing with human rights and humanitarian assistance; diplomats; the media; and organizations sponsoring development and democratization programmes.

The Pearson Centre offers national and international, multidisciplinary individuals and groups the opportunity to examine specific peacekeeping issues and update their knowledge of the latest peacekeeping practices. The Centre offers multifaceted curriculum of special interest to all stakeholders associated with peacekeeping operations. It offers an extensive schedule of conferences, seminars, workshops, training, and education courses. The Centre also sponsors field research with deployed peacekeeping missions, and a Visiting Scholars Program.

\section{Minorities at Risk Project}

Ted Robert Gurr, Principal Investigator Michael Haxton, Project Coordinator Michael Dravis, Research Associate Center for International Development and Conflict Management (CIDCM) Suite 0145, Tydings Hall

University of Maryland

College Park, MD 20742-7231, USA

Tel.: (301) 314-7706

Fax: (301) 314-9256

E-mails: tgurr@bss1.umd:edu

mhaxton@bss1.umd.edu

m-mdravis@bss1.umd.edu

The project has compiled and is analysing detailed information on the status and conflicts of 270 politically active communal groups in 1990-95. Phase III of the project, just completed, includes this information on each group:

- a brief overview of group history and status;

- 1995 population estimates and map(s) of group's spatial distribution;

- a chronology of events initiated by or affecting the group from 1990 through 1995;

- a detailed coding of 1990-95 information on the group's distinguishing traits, cohesion, inequalities, discrimination, grievances, political organization, and international support;
- coded data on group involvement in anti-government protest, rebellion, and communal conflict from 1945 to 1995 (coded annually from 1985 onward);

- an assessment of short-term prospects for improvements or deterioration in group status.

This information is being analysed for the following purposes:

- testing models of factors (e.g., group inequalities, mobilization, political environment) most closely linked to magnitudes of ethno-political conflict and conflict escalation;

- the identification of groups with the highest risk of future conflict and repression;

- the comparative assessment of domestic and international strategies for improving the status of ethno-political groups and reducing the potential for conflict and repression;

- regional and global assessments of trends in ethno-political conflict.

The systematic identification of groups with highest risks of future conflict and repression provides the basis for risk assessments (or very early warnings) that are being made available to multiple audiences including NGO representatives, national and international policy makers, and scholars. Results for African groups will be presented to and discussed with NGO representatives and European policy makers at a meeting convened by International Alert (London) in September 1996.

\section{Sources of Funding}

United States Institute of Peace, National Science Foundation, Korea Foundation, International Alert (London)

\section{Future Plans}

In the summer of 1996, the edited narrative materials and assessments on each group were made available on the World Wide Web through home pages at the University of Maryland and International Alert. Selected risk assessment indicators for each group are included.

Funds are being sought for: periodic updating of chronologies and assessments through the year 2000; improving the quality and graphic display of WWW materials; the inclusion of maps and source bibliographies for each group.

Gurr, T. R. 1993. Minorities at Risk: A Global View of Ethnopolitical Conflict. Washington, D.C.: U.S. Institute of Peace.
Gurr, T. R., and B. Harff (eds). July 1994. "Early Warning of Communal Conflicts and Humanitarian Crises." Journal of Ethno-Development, 4.

Gurr, T. R. 1994. "People Against States: Ethnopolitical Conflict and the Changing World System." International Studies Quarterly, 38:347-77.

Harff, B., and T. R. Gurr. 1995. "Victims of the State: Genocides, Politicides and Group Repression from 1945 to 1995." PIOOM Newsletter and Progress Report, 7 Winter, 24-38.

Gurr, T. R., and B. Harff. 1996. Early Warning of Communal Conflict and Genocide: Linking Empirical Research to International Responses. Tokyo: UN University Press. (forthcoming)

More information on the Minorities at Risk Project (all three Phases) can be found on the following web-site: http:// wizard.ucr.edu/ wm/M@R.HTM (Please note that the lower case/upper case distinctions are important). This web-site was created by Will $\mathrm{H}$. Moore who was a Senior Researcher on Phase III. (Department of Political Science, University of California, Riverside, Idyllwild, CA 92549; will.moore@ucr.edu).

PANDA-Protocol for the Assessment of Nonviolent Direct Action

Doug Bond, Associate Director

Program on Nonviolent Sanctions and

Cultural Survival

Center for International Affairs

Harvard University

1737 Cambridge Street

Cambridge, MA 02138, USA

Tel.: (617) 495-7705

Fax: (617) 496-8562 or 495-8292

E-mail: dbond@cfia.harvard.edu

PANDA project members have been working with the Kansas Event Data System(KEDS) development team for several years to extend and refine the dictionaries used by the KEDS automated sparse parsing program for use in the near-real time development of worldwide interaction event data. The KEDS program operates with a transparent and easily modifiable set of dictionaries that defines its operating protocol. PANDA project members have developed a set of dictionaries to facilitate the testing of propositions related to nonviolent direct action and the early warning of violence. The utility of the PANDA protocol for early warnings on conflict is premised in part upon the notion that nonviolent struggle may serve

Refuge, Vol. 15, No. 4 (1996) 
as a functional substitute for the violent prosecution of conflict. PANDA's focus on nonviolent alternatives to waging conflict constitutes an explicit recognition that while conflict is inevitable, violence is not necessarily the only option, and accommodation is not always possible or desirable. In the face of genocide, for example, a moral imperative dictates against compromise. PANDA's early warnings on conflict, then, are designed to illuminate conflict interactions where physical and coercive force is not employed, even as accommodative exchanges are ruled out. By monitoring and examining event reports with a "data lens" that is sensitive to nonviolent direct action, PANDA tracks the evolution of conflict manifest in both violent and nonviolent forms of action. This effort is aimed at developing a better understanding of the conditions, accelerators, triggers and processes by which some situations of conflict erupt into violence.

Bond, D. 1994. "Nonviolent Direct Action and the Diffusion of Power." In Justice without Violence, edited by $\mathrm{P}$. Wehr, $\mathrm{H}$. Burgess and G. Burgess. Boulder: Lynne Rienner Publishers.

Bond, D., and B. Bennett. 1994. "The Practice of Democracy: Global Patterns and Processes in 1990." Paper presented at the XVI World Congress of the International Political Science Association in Berlin.

Bond D., B. Bennett, W Vogele, and others. 1994. "PANDA: Interaction Events Data Development Using Atomated Human Coding." Paper presented a the ISA annual meeting in Washington, D.C.

Bond, D., and W. B. Vogele. 1995. "Profiles of International 'Hotspots'" Prepared for the U.S. General Accounting Office.

\section{Refugee Early Warning Project}

Susanne Schmeidl

Centre for Refugee Studies

York University

York Lanes, 3rd Floor, 4700 Keele Street North York, Ontario, M3J 1P3, Canada

Tel.: (416) 736-5663

Fax: (416) 736-5837

E-mail: schmeidl@yorku.ca

J. Craig Jenkins

Department of Sociology

The Ohio State University

300 Bricker Hall, 190 North Oval Mall

Columbus, Ohio 43210, USA

Tel.: (614) 292-1411

Fax: (614) 292-6687

E-mail: cjenkins@magnus.acs.ohio-state.edu
We are working on the development and empirical assessment of causal model of conditions associated with refugee flight by country of origin. Data is collected from both the United Nations High Commissioner for Refugees and the U.S. Committee for Refugees for 1964-1995. Data is collected by country of origin, with information on the country of asylum. Data on the internally displaced is also available. Initial analysis for 1971-1990 and future analysis for the 1990s is under way.

Schmeidl, S. 1997. "Exploring the Causes of Forced Migration: A Pooled Time-Series Analysis, 1971-1990." Social Science Quarterly, June. (forthcoming)

Schmeidl, S., and J. C. Jenkins. 1996. "The Growth of the World Refugee Crisis: An Overview." In Under Threat, edited by Lubomyr Luciuk and Martin S. Kenzer. Toronto: University of Toronto Press. (forthcoming)

Jenkins, J. C., and S. Schmeidl. 1995. "Flight from Violence: The Origins and Implications of the World Refugee Crisis." Sociological Focus, 28(1):63-82.

Schmeidl, S. "Comprehending Forced Migration: The Evolution of a Global Problem over the Past Three Decades: 1964-1994." Currently under review at International Migration Review.

Schmeidl, S., and J. C. Jenkins. "The Early Warning of Refugee Migrations: Problems Constructing an Indicator Model." Currently under review at International Migration Review.

\section{UN Fact-Finding and Intelligence-Gathering}

Walter Dorn

Vice-President and UN Representative Science for Peace

University College, University of Toronto Toronto, Ontario, M5S 3H7, Canada

Tel./Fax: (416) 978-3606

Fax: (416) 978-2797 (Trinity College)

E-mail: wdorn@chem.utoronto.ca

This ongoing study examines how the UN gathers and uses information for preventive diplomacy, early warning and the management and resolution of conflict. Several historical and recent case studies are being carried out to learn lessons for the present and future:

- early/late warning in Korea (1950);

- the UN role in the Cuban Missile Crisis;

- Intelligence and peacekeeping: The UN Operation in the Congo (1960-64);

- early warning in Rwanda;
- information-gathering in the former Yugoslavia for peacekeeping, sanctions monitoring and the international criminal tribunal.

The project also looks at present practices on information/intelligencegathering in the UN and evaluates proposals for improvements.

One aspect of the project concerns technologies for peace (peacekeeping, arms control, the prevention, management and resolution of conflict) and how they are used by the UN.

Dorn, W. 1995. "Intelligence and Peace-Keeping: The UN Operation in the Congo 1960-64." In A. Walter Dorn and David J. $\mathrm{H}$. Bell International Peace-keeping Vol. 2(1):11-33.

Dorn, W. 1995. “Keeping Watch for Peace: Fact-finding by the UN Secretary-General," In E. Fawcett and H. Newcombe United Nations Reform: Looking Ahead after Fifty Years, pp. 138-54. Toronto: Science for Peace.

Dorn, W. 1996. "UN Information Systems for Peace and Security." In International Information: Documents, Publications and Information Systems of International Governmental Organizations, edited by P. Hajnal. Libraries Unlimited. (forthcoming)

\section{Individual Early Warning Research Efforts}

Aldo A. Benini

170-C Brisco Road

Arroyo Grande CA 93420, USA

Tel.: (805) 481-2135

Daytime fax: (805) 481-6609

E-mail: abenini@slonet.org

Anthony de V. Minnaar

Centre for Socio-Political Analysis

Human Science Research Council HSRC

Private Bag X41

Pretoria 0001, Republic of South Africa

Tel.: (012) 202-2441

Fax: (012) 202-2510

E-mail: advm@socdyn.hsrc.ac.za

\section{Sam Pretorius}

Centre for Sociopolitical Analysis

Human Science Research Council HSRC

Private Bag X41

Pretoria 0001, Republic of South Africa

Tel.: (012) 202-2300

Fax: (012) 202-2510

E-mail: spjp@socdyn.hsrc.ac.za

Abstract of Preliminary Research Report (for a copy contact Aldo Benini) 


\section{Persistent Collective Violence and Darly Warning Systems: The Case of KwaZulu-Natal, South Africa}

One of the little known specifics of the democratic transition in South Africa 1990-1994 is its system of early warning on political violence. The strong role that grassroots organizations played in monitoring affected communities and suspected perpetrators set it apart from systems that are driven primarily by academics. Academics were important for the analysis of the reports collected by the popular movement and for formulating warnings on trends and hot zones which the transitional government as well as the media actively demanded. This paper describes the mechanisms and analyses data from the province of KwaZulu-Natal, where high levels of political violence continued for much longer than in the rest of the country. Using regression techniques, we show that the violent behaviour of the main political antagonists changed significantly after the April 1994 national elections. Also the violence followed different causative patterns in the various subregions. Profiles derived in 1994 and 1995 informed the government's decision to postpone regional elections in KwaZulu-Natal three times before they could be held in June 1996 in a climate of relative tranquillity.

Helen Fein, Director

Institute for the Study of Genocide

46 Irving Street

Cambridge, MA 02138, USA

Helen Fein is a leading scholar on genocides. She has published extensively on this topic, as well as on the issue of the early warning of genocides.

Fein, H. (ed.) 1994. The Prevention of Genocide: Rwanda and Yugoslavia Reconsidered. New York: Institute for the Study of Genocide. (Also contributor)

Fein, H. (1990) 1991 (new introduction). "Genocide: A Sociological Perspective." Special Issue of Current Sociology. Sage Publications.

Fein, H. (ed.). 1989. Genocide Watch. New Haven: Yale University Press. (Also contributor).

Fein, H. 1994. "Tools and Alarms: Uses of Models for Explanation and Anticipation." Journal for Ethno-Development, July, 31-35.

Fein, H. 1994. "Prediction, Prevention and Punishment of Genocide: Observations on Rwanda and Puture Policies." Refuge: Canada's Periodical on Refugees, 5(15):1-4.

Fein, H. 1984. "Scenarios of Genocide: Models of Genocide and Critical Responses." In The Book of the International Conference on Holocaust and Genocide: Towards Understanding, Intervention and Prevention of Genocide, edited by I. Charney and S. Davidson. Boulder, Co: Westview Press.

Fein, H. 1992. “Dangerous States and Endangered Peoples." In Early Warning and Conflict Resolution, edited by K. Rupesinghe and M. Kuroda. London: St. Martin's Press.

\section{Herbert Hirsch}

Virginia Commonwealth University

Department of Political Science and

Public Administration

P.O. Box 842028

Richmond Virginia 23284-2028, USA

Fax: (804) 828-7463

Hirsch, Herbert. 1996. Genocide and the Politics of Memory: Studying Death to Preserve Life. University of North Carolina Press.

The last two chapters of this book are devoted to the prevention of genocide. Within the context of that discussion, I take a brief look at some of the proposals for early warning and I extend the analysis to consider other aspects of international law and a change in the way nation states are viewed.

Ben Hunt, Assistant Professor of Politics New York University

715 Broadway, 4th floor

New York, New York 10012, USA

Tel.: (212) 998-8503

Fax: (212) 995-4184

E-mail: hunt@acf2.nyu.edu

\section{Political Indicators of War Escalation}

This project is aimed at developing a leading political indicator of a government's intention to escalate conflict to war through its attempts to mobilize public opinion in the mass media. Since all governments, regardless of how authoritarian, prefer to have this support before undertaking a risky action like war, the model is applicable across the board. Even in countries with an 'open' media system, governments maintain enough influence over opinion leading efforts to generate a meaningful indicator. This work is based on an idea Karl Deutsch had back in the mid-1950's, when he was writing about using media as 'an early warning network.'
The project is described in a forthcoming book by Ben Hunt(Fall 1996) Getting to War. University of Michigan Press. He tests his model with a range of statistical and case study analyses, and the results are striking. Even for wars that took the world by surprise (e.g., Falklands/ Malvinas), the models provide a clear prediction of imminent conflict.

\section{Louis Kriesberg}

Maxwell School of Citizenship and

Public Affairs

Program on the Analysis and Resolution of Conflicts

410 Maxwell Hall

Syracuse, New York 13244-1090, USA

Tel.: (315) 443-2367

Fax: (315) 443-3818

Louis Kriesberg is examining the ways constructive struggle are and might be conducted at various stages of social conflicts. This analysis helps specify policies that intermediaries and partisans in conflicts can pursue to avoid, limit, end, and prevent destructive conflicts. Cases of ethnic and other communal conflicts that exhibit relatively effective applications of problem-solving conflict resolution approaches are also examined. His work focuses as well on the ways to coordinate various intermediary and partisan efforts to wage constructive struggles and to pursue problem-solving conflict resolution methods.

Kriesberg, L. 1996. "Preventing and Resolving Destructive Communal Conflicts." In The International Politics of Ethnic Conflict: Theory and Evidence, edited by P. James and D. Carment. University of Pittsburgh Press. (forthcoming)

Kriesberg, L. 1992. International Conflict Resolutions: The U.S.-USSR and Middle East Cases. New Haven: Yale University Press.

Kriesberg, L., and S. Thorson (eds). 1996. Timing the De-Escalation of International Conflicts. Syracuse Studies and Peace Conflict Resolution. (forthcoming)

Kriesberg, L. 1996. "Varieties of Mediating Activities and Mediators in International Relations." In Resolving International Conflicts: The Theory and Practice of Mediation, edited by J. Bercovitch. Lynne Rienner Publishers.

Kriesberg, L. 1994. “Conflict Resolution." In edited by Peace and World Security Studies: A Curriculum Guide, edited by M. Klare. Lynne Rienner Publishers.

Kriesberg, L. 1993. "Intractable Conflicts." Peace Review 5(4):417-21.

Refuge, Vol. 15, No. 4 (1996) 
Kriesberg, L. 1994. "Regional Conflicts in the Post-Cold War Era: Causes, Dynamics, and Modes of Resolution." In World Security: Challenges for a New Century, edited by $M$. Klare and $D$. Thomas. New York: St. Martin's Press.

Andrea Smutek-Riemer

Veronikagasse $38 / 230$

A-1170 Wien, Austria

Tel./Fax: (+43 1) 405-1729

E-mail: smutek@isis.wu-wien.ac.at

The research program on "The Systemicevolutionary Extended Signal Approach"

(C) Dr. Andrea K. Smutek-Riemer) entails several projects both theoretical (backdrop: Signal Approaches) and case studies (period of analysis 1987 to 1997).

The research process is systematic and evolutionary. The time frame is from 1994-2000. The basic outline of this research is completed as are two cases: one on the former Yugoslavia (a pilot project) and a nearly finished one on Turkey (it is going to be continued until 1997). Cases on Slovakia, the Czech Republic and Hungary are going to follow in 1997 and 1998. The last project is comparison of all these cases.

Vetschera, Heinz/Smutek-Riemer, Andrea. 1992. "Signale zur Früherkennung von krisenhaften Entwicklungen am Beispiel der Entwicklung zur Jugoslawienkrise." In Sicherheitspolitik Deutschlands: Neue Konstellationen, Risiken, Instrumente, edited by Heydrich, Wolfgang et al., 287330. Baden-Baden.

Vetschera, Heinz/Smutek-Riemer, Andrea. 1993. "'Signale' zur Früherkennung von krisenhaften Entwicklungen am Beispiel der Entwicklung zur Jugoslawienkrise." Österr. Milit. Zeitschrift. 1:17-25. (Both papers introduce a new approach in early warning using the crisis in former Yugoslavia.)

Smutek-Riemer, Andrea. 1995. "Die Früherkennung von Krisen zwischen Anspruch und Wirklichkeit: Anforderung an ein Krisenfrüherkennungssystem aus österreichischer Sicht." Allgemeine Schweizerische Militärzeitschrift, 3:22-24.

Smutek-Riemer, Andrea. 1995. "Krisenfrüherkennung: Die Quadratur des Kreises?" Soldat und Technik, 258-60. (The articles provide an overview of prerequisites in the area of early warning.) $a$

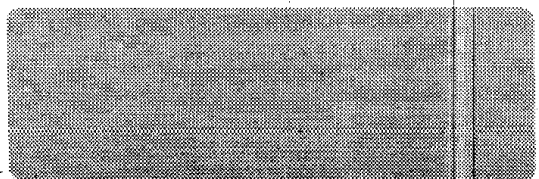

\section{EWNET-L Electronic Discussion Group on Early Warning Issues}

\section{Background}

The puppose ot this list is to provide a plafform for mutual discussion for researchers (acadernic and non-acedemic) and policy makers on issues related to early warning. This includes the exchange of research ideas, information etc on Early. Waming

Early Warning here is very broadly defined as the Early Waring of humanitarian disasters, which includes ethnic/communal conflict, genodides/politicides, wars, refugee migrations ete. We hope to link as many people together into this worldwide network in order to create a community of Early Waming scholars and strengthen, ties between the research and policy community. Currently there are $90+$ individuals and organizations signed up on EWNET $\mathcal{L}$ and we are growing monthly.

\section{Hort to Joh}

EWNET-L is a closed list in order to avoid commercial abuse of the list. Therefore, you cannot simply join EWNET-L as other email discussion groups. You need to be added manually by the list-manager. In order to be added send a message to: EWNET Oyotku.ca stating the following:

1. Who you are and what work you do

2. Your interest in early waming

3. Your coordinates (mailing address etc)

This information will aid us in keeping our database on the "early waming community" up to date. In addition, frequently a message will be sent around to everyone on IWNET-L introducing new members so that participants know who are the members of EWNET-L. Please consider becoming part of this discussion list:

Also, we will be working on a follow-up issue of Refuge in late 1997 to (a) critically respond to issues raised; (b) provide space to address issues that did not receive enough attention; and (c) give voice to new or different efforts that were left out in the current issure.

Please send your requests to join EWMET-L, and/or your contributions to Sussme Schmeiall<EWMETTQy orkikcas or sichmeidloy orku.cas. Phone (416) 736-5883. 


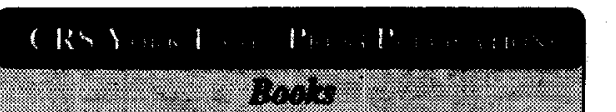

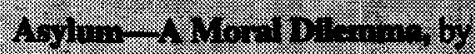

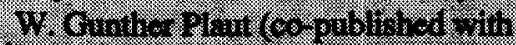
Greonwood Publications 1935): 91996

r.

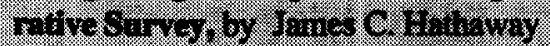
and Johin A. Dent (1995): 511.95

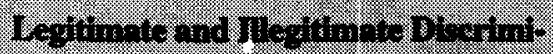

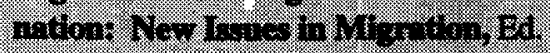
by Howard Ndeiman (1995); 122.95

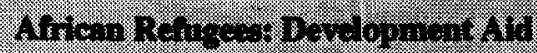
and Ref, wimion, Editod by Rowzad

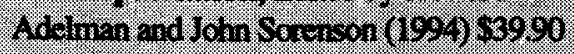

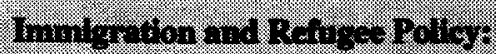
Australitiand Camado Compord.

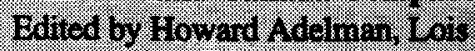
Foster, Allan Berowskd and Meyer: Burstein (1994)

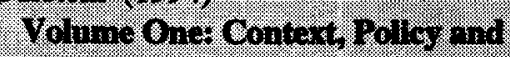
Implementition: $\$ 2495$

Volume Tho: Seulement and Impact $\$ 24.95$

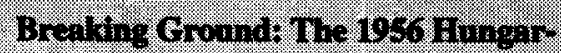
Inn Tmmigration to Caninda, Edited by Rober. H. Keyseringk (1993), 012.95

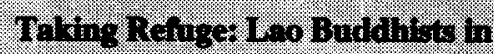
North America, by Peany Van Esterik (1992): $\$ 12.95$

revige or Aly lim A Choted ror Cingdis, Edited by Howard Adelman and C. Miehael Lanphier (1991); 518.95

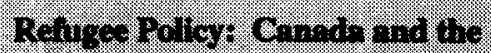
Unirad St in, Edited by Howand Adelman $(1991)$ ) 520.95

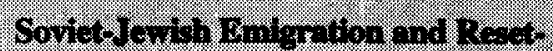

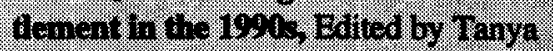
Bacok and Relcr. I Emm (1931). $\$ 15.95$

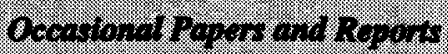

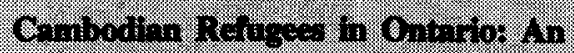

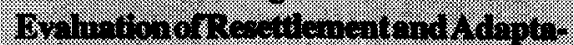
60, by Tanet Melellan (1995): S12.95

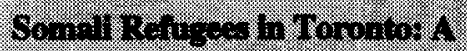
Prona by Edryard OpokerDapash $(1995) \div .312 .95$

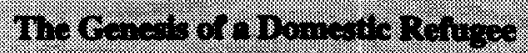

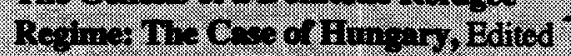

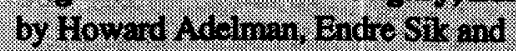
Cersa Tessonyi (1994), S1495

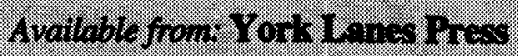

\section{Back Issues of Refuge}

The rollowing is a ist. of general and hematic issues of

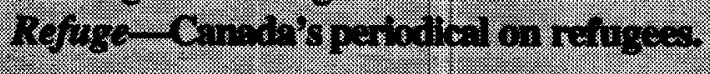

2. 3.

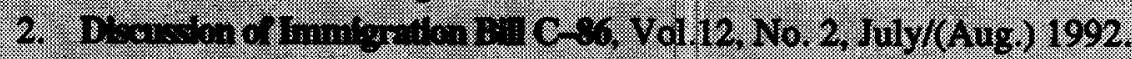

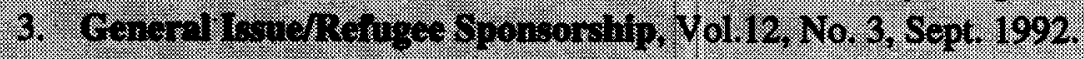

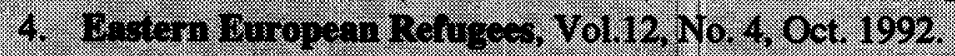

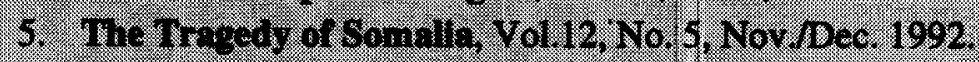

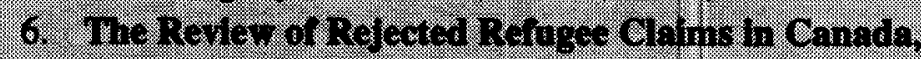
Vol.12. No. 6. Jamuari 1993 .

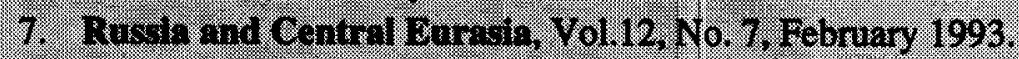

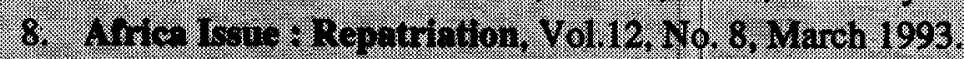

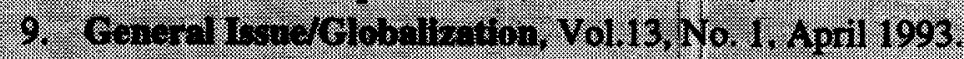

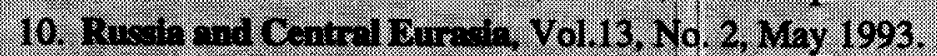

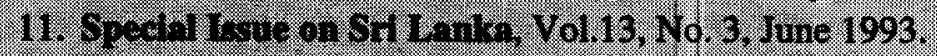

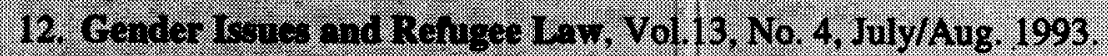

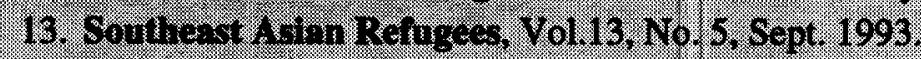

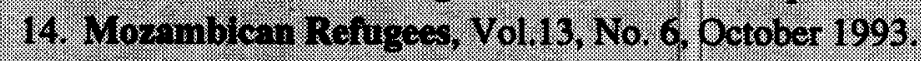

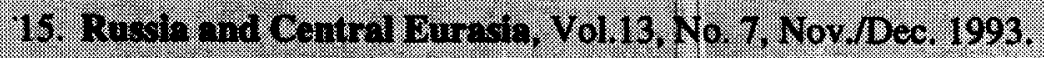

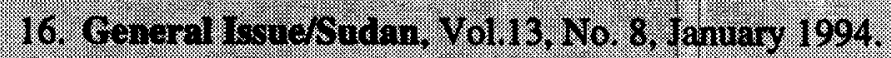

17. Integration of Rerugees. The Conadinin Empertence,

Yolil 3. Yo. 9. February 1094 .

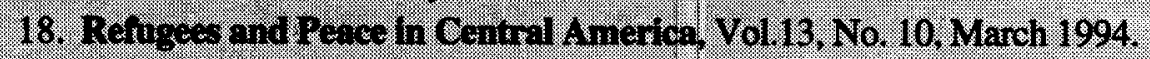

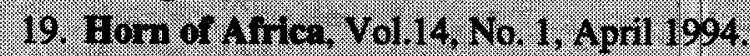

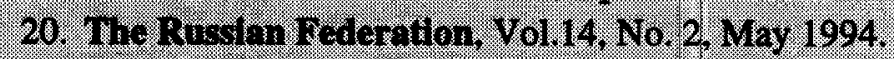

21. The rommer Tugosiovia, Voll14, No. 3. JunelJuly 1994.

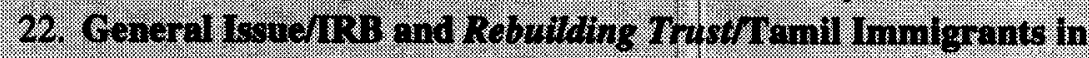
Conada. Yoll14. Mo. 4. Aug.Sept. 1994.

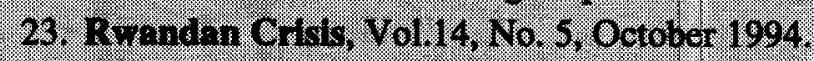

24. Reruger Revenlement in Rrmel, Vol.14, No. 6. Nov. 1994.

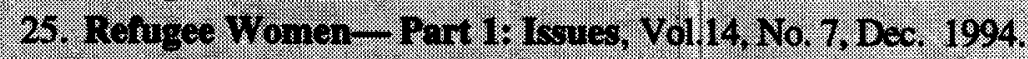

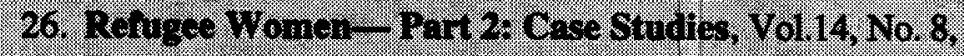
han. 1995 .

27. Ti. Sare Whird Country Concept. Vo1.14. No. 9 Febrarary 1995 .

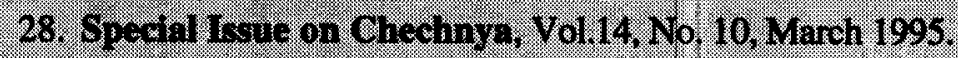

Single copyt 86.50, 10\% discount on 3-9 issues. (copies). 20\% discount on 10 issues (Copies) or nore. Special discounis are avaliable for students and exclusively volunterer-run NCOS. P. O aecepted.

Please send your orders to:

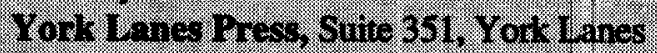

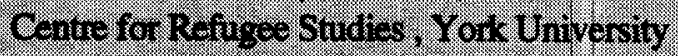

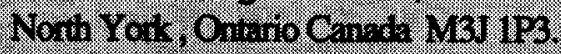

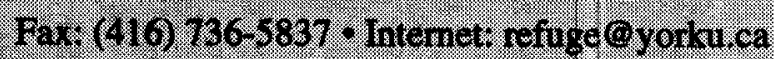




\author{
Refuge \\ Centre for Refugee Studies \\ Suite 351, York Lanes \\ York University \\ 4700 Keele Street, North York \\ Ontario, Canada M3J 1P3 \\ Phone: (416) 736-5843 \\ Fax: (416) 736-5837 \\ Internet: refuge@yorku.ca
}

\title{
GALL FOR PAPERS \\ REFUGEe IDENTITY IN Resetrlement CounTries
}

The Centre for Refuge Studies will soon publish a Sperial issue of Refuge on Refugce Identity in Resettlemont Combres. Tho Issue wil address toptess such as:

- Cender and refiger ridomity.

- Processing refugees and identity

- Ideatiy (refromation among rofugeos.

- Immigration andidientity

- civic identry and civic participation among refige-er in res-ttlement colmates

Papers are now beting hited on these issues and other related areas will be constiered. Please send your contributions ssap, but not later than Jamiary $29,1997$.

Anticles may not exceed 16 pages (double-spaced) or about 4000 words. Short papers of about9m) words are also velcone: Word processed submissions may be sent in dise or by e-manl.

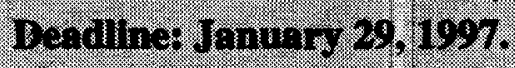

For further derall, please contact:

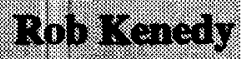

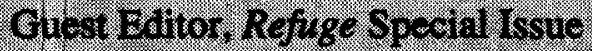

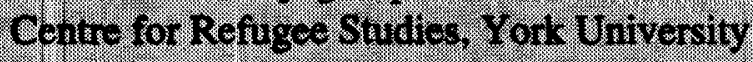

North Tork. Ontario MBt ip3. Canada

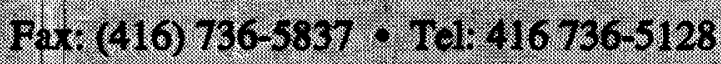

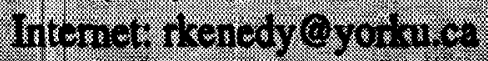

